\title{
INDAZIFLAM APPLICATION IN NEWLY TRANSPLANTED ARABICA COFFEE SEEDLINGS
}

\author{
Carolina Alves Gomes ${ }^{1}$, Laís Franchini Pucci², Deivide Patrik Alves ${ }^{3}$, Vitor Alves Leandro ${ }^{4}$, \\ Gustavo Antônio Mendes Pereira ${ }^{5}$, Marcelo Rodrigues dos Reis ${ }^{6}$
}

(Received: June 14, 2019; accepted: August 19, 2019)

\begin{abstract}
Weed management is one of the main and most problematic cultural practices used in coffee plantations. Slow growth, broad spacing associated with scarce registered products for weed control at an early crop stage, are the main problems faced by producers. Therefore, it is desirable for new herbicide molecules to be registered for this crop, as is the recent case of indaziflam. This study aimed to know the influence of indaziflam on the morphological characteristics of coffee plants and to propose alternatives to reduce its effects on plants. Therefore, the effects of this herbicide on two arabica coffee cultivars were studied, as well as the association of this herbicide with protection of the seedling collar (PVC pipes and bovine manure). Controls on weeds, possible injury on seedlings and effects on the main morphological characteristics of coffee plants were evaluated. Although treatments with the use of indaziflam cause intoxication in the seedlings, a reduction in plant damage was observed over time, and the damage was insignificant. In general, it was observed that cultivar IBC 12 suffered minor injuries, but it is more sensitive to the presence of indaziflam, since it presented greater damage in the morphological variables. The use of manure with the PVC pipe can be an alternative to reduce the effects of this herbicide, as it reduced the effects of the product on the root system of this cultivar. It is concluded that the application of indaziflam causes mild symptoms in coffee plants independent of the planted cultivar. Indaziflam causes reduction in seedling morphology, and this effect is dependent on the cultivar used. The use of manure associated to the PVC pipe can be an alternative to reduce the effects of indaziflam, mainly in the root system of coffee plants.
\end{abstract}

Index terms: Coffea arabica L., weed, chemical management, phytotoxicity.

\section{APLICAÇÃO DE INDAZIFLAM EM MUDAS RECÉM TRANSPLANTADAS DE CAFÉ ARÁBICA}

RESUMO: O manejo de plantas daninhas é um dos principais problemas enfrentados pelos produtores de café, uma vez que a culura possui crescimento lento, espaçamento largo e há escassez de herbicidas registrados para o controle dessas plantas na fase inicial da lavoura. Sendo assim, é desejável que novas moléculas herbicidas sejam registradas para esta cultura, como é o caso recente do indaziflam. Este trabalho teve como objetivo descrever os efeitos do indaziflam sobre as características morfológicas de mudas de café bem como, propor alternativas para reduzir tais efeitos sobre as plantas. Para isto, foram estudados os efeitos deste herbicida em duas cultivares de café arábica e a associação do indaziflam com proteção do coleto das mudas (canos de PVC e esterco bovino). Foram avaliados o controle sobre as plantas daninhas, as possíveis intoxicações nas mudas e os efeitos sobre as principais características morfológicas das mudas de café. Apesar do indaziflam causar intoxicação inicial nas mudas, os danos causados a planta tornaram-se insignificantes ao longo do crescimento do cafeiro. No geral, os sintomas visuais de intoxicação foram menores na cultivar IBC 12, todavia a presença do indaziflam causou maiores danos nas variáveis morfológicas da planta, tais como redução da matéria seca do caule e da área foliar. O uso do esterco com o cano de PVC reduziu a intoxicação pelo indaziflan do sistema radicular das mudas de cafeeiro. Conclui-se que a aplicação do indaziflam causa leves sintomas de intoxicação nas mudas de café independente da cultivar plantada. O indaziflam causa redução na morfologia das mudas, sendo este efeito dependente da cultivar. O uso do esterco associado ao cano de PVC reduz os efeitos do indaziflam, sobretudo no sistema radicular de mudas de café, apresentando-se como uma alternativa promissora para uso seguro do herbicida.

Termos para indexação: Coffea arabica L., planta daninha, manejo químico, fitointoxicação.

\section{INTRODUCTION}

Brazil is the largest producer, exporter and consumer of offee in the world, with approximately $32 \%$ of the world production. Brazil has approximately 2,209 hectares of planted area between the Arabica and Conilon species, and production of 49.67 million bags; Minas Gerais is the most active state, with 1,180 planted hectares and production of about 28.5 million bags per year (CONAB, 2019).

In perennial crops such as coffee, cultural practices are more complex, once differences between the initial growth stages and crop production are required. Weed management in this crop is divided into two main stages, up to two years, called young crop and, after two

1,2,3,4,5,6, Universidade Federal de Viçosa Campus Rio Paranaíba /UFV-CRP Instituto de Ciências Agrárias/ IAP - Km 7 Zona Rural, MG 230 - Rodoviário - Rio Paranaíba - MG - 38.810-000 - Rio Paranaíba - MG- carol.agomes11@gmail.com, laisfpucci@gmail.com, deividepatrikalves123@gmail.com, vitoralves1998@hotmail.com, gustavogamp@hotmail.com, marceloreis@ufv.br 
years, it is known as management in adult coffee. The management in the young crop is the most important and complex, as the culture presents very slow initial growth and wide spacing, which makes it impossible to cultivate foliage capable of suppressing weed growth (Fialho et al., 2011).

The main weed control methods in young coffee plants are associations of chemical with mechanical management. However, mechanical management is very dependent on land slope and labor availability. On the other hand, chemical management shows a difficulty in terms of reduced high-efficiency products that have a longer control period and are selective for the crop (Silva et al., 2017).

The main herbicides used for weed control in coffee crops are the repeated applications of glyphosate and oxyfluorfen (Magalhães et al., 2012). Thus, the absence of rotation of action mechanisms in coffee tree is a concern, since it can lead to the selection of tolerant and/or resistant weeds, caused by the intensive use of herbicides, as already observed for several species in the use of glyphosate (Christoffoleti et al., 2016). In the case of oxyfluorfen, in recent years, several producers have reported that this product has presented a loss of efficiency, but without scientific proof so far.

The herbicide indaziflam $(N-[(1 R, 2 S)-2,3-$ dihydro-2,6-dimethyl-1H-inden-1-yl]-6-[(1R)-1fluoroethyl]-1,3,5-triazine-2,4-diamine) is a new alternative for use in coffee crop, introduced in the Brazilian market in 2016, is a product used in pre-emergence, also registered for weed control in sugarcane crop and fruit plantation. It belongs to the chemical group alkylazine, presenting a broad spectrum of action and long-lasting action, besides efficiency with low dose applications (Silva et al., 2017; Guerra et al., 2013). This compound acts in cell wall biosynthesis, inhibiting its formation, not affecting the synthesis of polysaccharide polymers (Myers et al., 2009; Kaapro and Hall, 2012). Considering that indaziflam also acts to inhibit the deposition of crystals in the cell wall, severely affecting cell formation, division and elongation, it can be observed that fully developed leaves are hardly affected (Guerra et al., 2013).

As a new herbicide on the market and with a long residual period (Brosnan et al., 2012), the use of indaziflam in the coffee crop needs to be studied. It is suspected that this product may cause injury in coffee seedlings, especially in the root system. Thus, the objective in this study is to know the influence of indaziflam on the morphological characteristics of coffee plants and to propose alternatives to reduce its effects on plants, using manure and PVC pipe.

\section{MATERIAL AND METHODS}

The experiment was carried out in the experimental area of the Univeridade Federal de Viçosa, Rio Paranaíba Campus city, from November 2017 to February 2018. A randomized block design was used in a factorial scheme; the first factor consisted of two coffee cultivars, IBC 12 and Catuaí Vermelho IAC 144, and the second factor consisted of five managements: application of indaziflam alone; indaziflam and PVC pipe; indaziflam, PVC pipe and manure; indaziflam and manure, in addition to a weed control, with 10 replicates. In the treatments that received herbicide application, the commercial product Alion $^{\circledR}$ was used at $150 \mathrm{~mL} \mathrm{ha}{ }^{-1}$ corresponding to $75.0 \mathrm{~g}$ a.i. of indaziflam. The application was performed using an automatic costal sprayer with a volume of $200 \mathrm{~L} \mathrm{ha}^{-1}$ at a range of $0.5 \mathrm{~m}$ on each side of the seedlings. This application was made after one week of installing the seedlings in the site.

In the treatments with PVC, pipes with 10 $\mathrm{cm}$ in diameter and $10 \mathrm{~cm}$ in height were used, buried $5 \mathrm{~cm}$ and $5 \mathrm{~cm}$ above the surface to prevent drainage to the plant collar and, for the treatments with manure, tanned cow manure was used (Figure 1).

Irrigation was carried out using drip tapes, to supply the need for water to the seedlings, according to rainfall and thermal variations observed during the conduction of the assay (Figure 2).

Weed control was evaluated at 30 days after application (DAA), and plant injury was evaluated in coffee plants at 30,60 and 90 DAA. Injury scores were given through a score scale in which $0 \%$ represents no injury and $100 \%$ represents plant death, according to SBCPD (1995).

At 90 days, plant height was measured, with a ruler graduated in $\mathrm{mm}$, from the collar base to the apical bud. At 120 days, the number of leaves was counted, and they were stored and identified for leaf area. The collar diameter was also measured at one centimeter of the soil with a $0.01-\mathrm{mm}$ digital caliper. Plagiotropic branches were also counted and the length of the first branches was measured at 120 DAA.

The roots were removed from the soil with water, to avoid losses of secondary roots, soon after they were washed. The roots were identified, as well as the stem and leaves, then dried in an oven at $70^{\circ} \mathrm{C}$ until reaching constant weight and weighed in a precision scale with a sensitivity of $0.01 \mathrm{~g}$. 


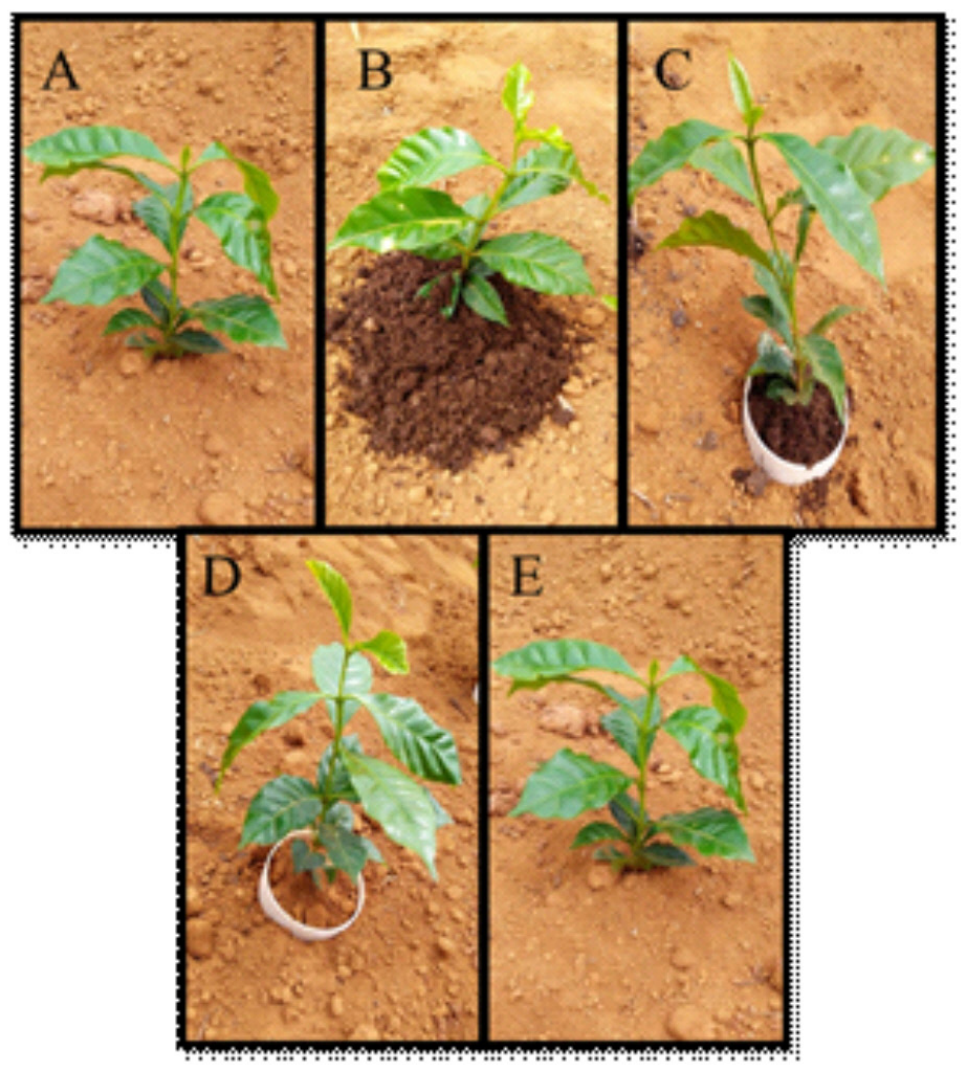

FIGURE 1 - Representation of the treatments tested: application of indaziflam alone (A); indaziflam and manure (B); indaziflam, PVC pipe and manure (C); indaziflam and PVC pipe (D) and weed control (E).

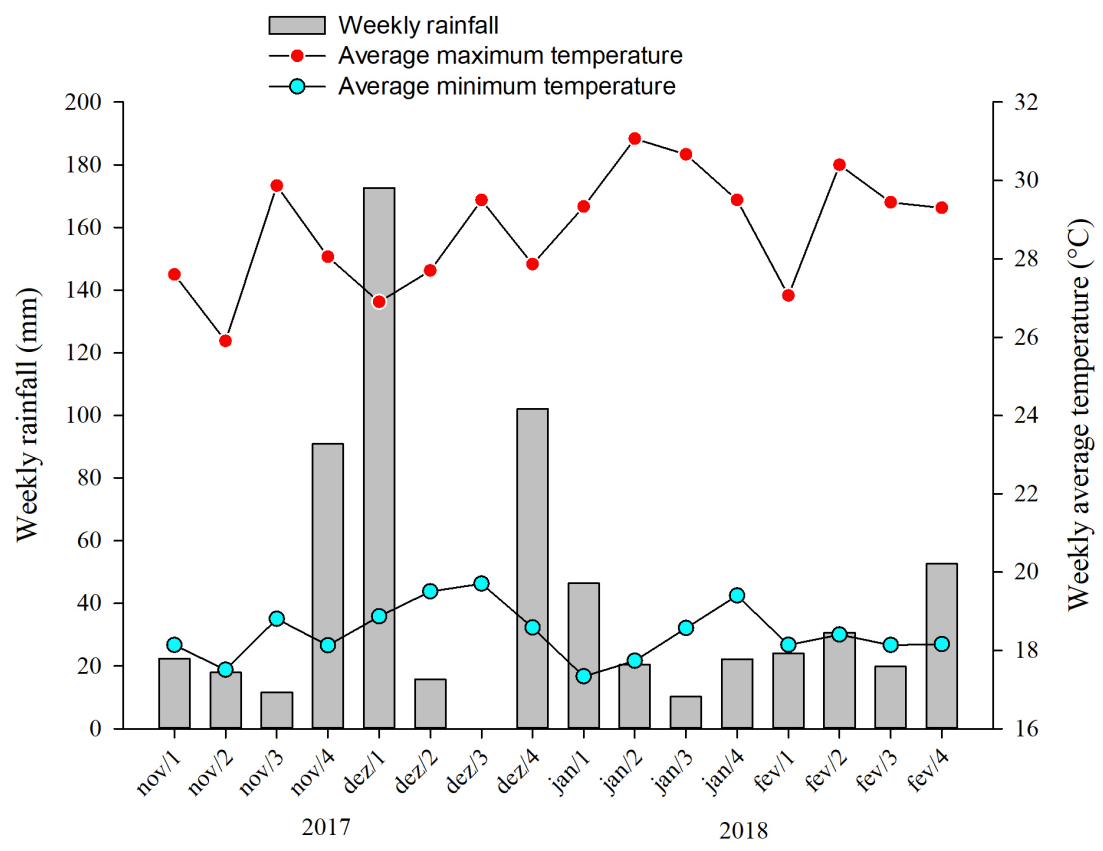

FIGURE 2 - Weekly rainfall and average maximum and minimum temperature during the conduction of the assay, Rio Paranaíba, MG. 
Leaf area was measured by photos of leaves taken on a white surface and submitted to Image $\mathrm{J}$ software, in square centimeters.

Data on weed control and seedling injury were descriptively analyzed, and bar graphs with their respective standard deviations were made using the SigmaPlot $12^{\circledR}$ software. The other variables were submitted to analysis of variance and, for the significant factors, the means were compared by the SNK test at 5\% probability; the software used was Speed Stat $1.0^{\circledR}$.

\section{RESULTS AND DISCUSSION}

The variables number of leaves, length of first branch and leaf dry matter, were not influenced by management or cultivars (data not shown).

The most abundant weeds in the area were wiregrass (Eleusine indica), nut grass (Cyperus rotundus L.), white charlock (Raphanus raphanistrum L.), beggar-ticks (Bidens pilosa) and showstar Blackfoot (Melampodium paludosum). Weed control was similar in all treatments (Figure $3)$. There was control efficiency in both cultivars and management adopted, above $85 \%$.

The efficiency of indaziflam in preemergence weed control has been demonstrated by Brosnan et al. (2011 and 2012) and Perry et al.
(2011) under temperate climate conditions at the dose of $60 \mathrm{~g} \mathrm{ha}^{-1}$. The control of annual grasses ranged from 80 to $90 \%$, up 195 DAA. Other studies carried out in Brazil also demonstrated that the application of indaziflam at above 100 $\mathrm{g} \mathrm{ha}^{-1}$ in pre-emergence of the species Ageratum conyzoides, Sida rhombifolia and Digitaria horizontalis resulted in a satisfactory control for a period up to 120 DAA (Christoffoleti et al., 2012; Nicolai et al., 2012).

However, Brosnan \& Breeden (2012) demonstrated that the application of indaziflam (52.5 $\left.\mathrm{g} \mathrm{ha}^{-1}\right)$ in the initial post-emergence of Digitaria ischaeemum and Poa annua is not efficient: the control was only $6 \%$ and $0 \%$, respectively, at 35 DAA.

There was plant injury independent of treatment, cultivar, and/or season evaluated. However, plant damage did not exceed $10 \%$ and $20 \%$ for cultivars IBC 12 and 144, respectively (Figures 4A and 4B). These values are within acceptable levels, since plants are expected to recover from the damage caused by the herbicide (Paiva et al., 2015), as observed in this study over the days. Cultivar IBC 12 was more tolerant than 144 due to lower symptoms and persisted for a shorter period.

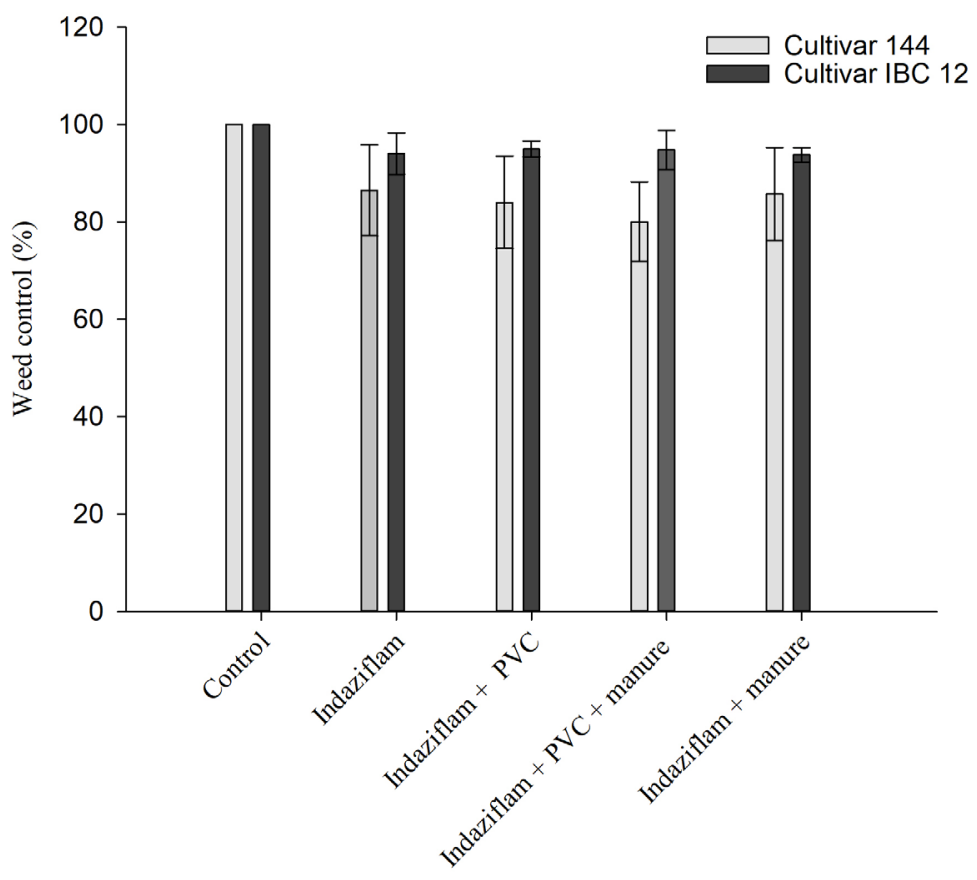

FIGURE 3 - Percentage of weed control in crops with coffee cultivars 144 and IBC 12, submitted to different management types at 30 DAA, bar represent standard deviation of the mean, Rio Paranaíba, MG, 2018. 

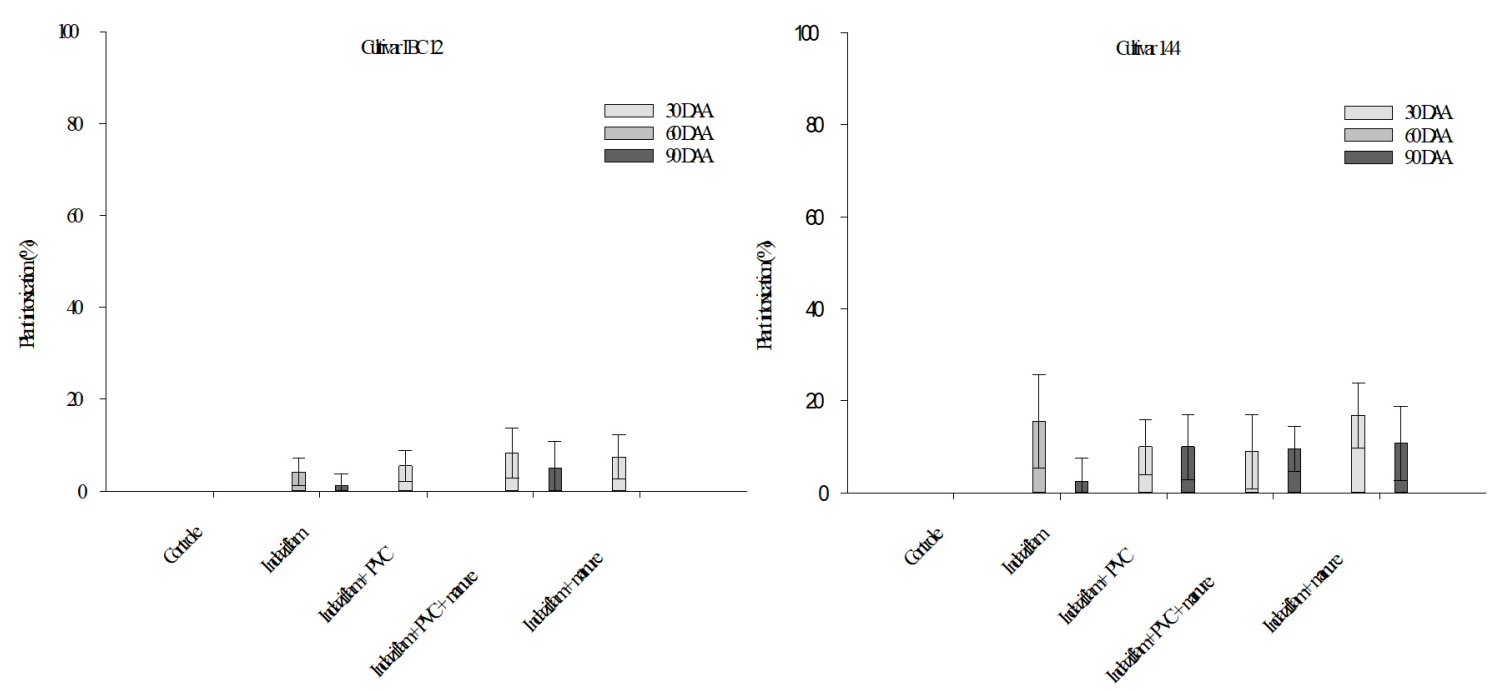

FIGURE 4 - Percentage of injury of coffee seedlings in crops with cultivars 144 (A) and IBC 12 (B), submitted to different management types, bar represent standard deviation of the mean, Rio Paranaíba, MG, 2018.

According to Guerra et al. (2013), indaziflam interrupts crystal formation in the cell wall, with no new leaves appearing. However, fully developed leaves will hardly be affected by indaziflam, since cell wall formation is already completed and no new cellulose synthesis occurs. In this study, the seedlings already had developed leaves and the technology of application adopted tended to reduce the contact of the new parts of the plant with the product, justifying the minor symptoms observed by the application of this herbicide.

Plant height of cultivar 144 was higher than that of cultivar IBC 12, regardless of the treatment to which they were submitted (Table 1). The treatments did not reduce the plant height of cultivar 144. However, it was observed that the use of indaziflam + PVC in cultivar IBC 12 considerably reduced plant height, compared to control.

As observed for plant height, the stem diameter of cultivar 144 was higher than IBC 12 in the control treatment (Table 2). This result was only reproduced with the use of the combination indaziflam + PVC + manure; for the other treatments, no difference between cultivars was observed. In the comparison within cultivars, the only difference observed was the larger diameter, when plants of cultivar IBC 12 were submitted to the combination indaziflam $+\mathrm{PVC}+$ manure, in relation to the use of indaziflam + PVC.

Means followed by the same lowercase letter in the column and uppercase in the row, do not differ statistically (SNK test, $p<0.05$ ).
The stem of Arabica coffee has reserve structures, being a relevant source of carbohydrates to supply the vegetative and reproductive needs of coffee (Ferreira et al., 2014). Plants with larger stem diameter enable the lower occurrence of plant tipping, improving coffee management (Tassone, 2016). Thus, this is a vegetative characteristic directly related to the resistance of the coffee plant to the wind (Carvalho, 2003), which in turn can cause irreversible lesions, leading the plant to tipping and death (Alcantara, 2012).

The number of branches of cultivar 144 was higher than that of IBC 12, regardless of the treatment, and there was no influence of management on this variable (Table 3 ).

Stem dry matter was higher in cultivar 144, compared to IBC 12 (Table 4). Cultivar 144 was not influenced by treatments. However, it was observed that the use of any of the treatments caused a reduction in this variable in relation to the control treatment in cultivar IBC 12.

Root dry matter was higher in cultivar 144 than in IBC 12 (Table 5). The treatments did not change this variable for cultivar 144. In IBC 12, it was observed that the use of Indaziflam alone and the combination indaziflam + PVC, reduced root dry matter. However, the use of manure reduced the damaging effect of herbicide application.

Yamashita et al. (2013) warn that herbicide, glyphosate, 2,4-D and oxyfluorfen drift may cause the abnormal development of Coffea canefora plants. França et al. (2010) report the drifting of increasing doses of glyphosate reduces the main morphological variables of coffee seedlings. 
TABLE 1 - Coffee plant height in crops with cultivars 144 and IBC 12, submitted to different management types at 120 DAA, Rio Paranaíba, MG, 2018.

\begin{tabular}{|c|c|c|c|c|c|c|}
\hline Treatments & & IBC 12 & & & 144 & \\
\hline Control & 18.23 & \pm 1.26 & a B & 29.58 & \pm 1.73 & a A \\
\hline Indaziflam & 16.39 & \pm 1.19 & $a b B$ & 26.99 & \pm 1.57 & a A \\
\hline Indaziflam + PVC & 13.70 & \pm 2.49 & b B & 29.07 & \pm 5.91 & a A \\
\hline Indaziflam + PVC + manure & 15.44 & \pm 2.62 & $a b B$ & 30.95 & \pm 2.61 & a A \\
\hline Indaziflam + manure & 15.39 & \pm 2.36 & ab B & 30.01 & \pm 4.34 & a A \\
\hline
\end{tabular}

Means followed by the same lowercase letter in the column and uppercase in the row, do not differ statistically (SNK test, $p<0.05$ ).

TABLE 2 - Stem diameter of coffee plants in crops with cultivars 144 and IBC 12, submitted to different management types at 120 DAA, Rio Paranaíba, MG, 2018.

\begin{tabular}{lcccccc}
\hline \multicolumn{1}{c}{ Treatments } & \multicolumn{7}{c}{ IBC 12} & & 144 & \\
\hline Control & 5.03 & \pm 0.17 & ab B & 6.73 & \pm 1.38 & a A \\
Indaziflam & 4.96 & \pm 0.31 & ab A & 5.37 & \pm 0.81 & a A \\
Indaziflam + PVC & 4.70 & \pm 0.25 & b A & 5.80 & \pm 0.94 & a A \\
Indaziflam + PVC + manure & 5.53 & \pm 0.59 & a B & 6.82 & \pm 0.49 & a A \\
Indaziflam + manure & 5.11 & \pm 0.61 & ab A & 6.18 & \pm 1.12 & a A \\
\hline
\end{tabular}

TABLE 3 - Number of branches of coffee plants in crops with cultivars 144 and IBC 12, submitted to different management types at 120 DAA, Rio Paranaíba, 2018.

\begin{tabular}{lllllll}
\hline \multicolumn{1}{c}{ Treatments } & & IBC 12 & & & 144 & \\
\hline Control & 3.05 & \pm 0.50 & a B & 5.03 & \pm 0.67 & a A \\
Indaziflam & 2.20 & \pm 0.95 & a B & 4.23 & \pm 1.21 & a A \\
Indaziflam + PVC & 1.15 & \pm 0.77 & a B & 3.55 & \pm 1.43 & a A \\
Indaziflam + PVC + manure & 2.50 & \pm 1.32 & a B & 5.15 & \pm 0.19 & a A \\
Indaziflam + manure & 2.25 & \pm 1.22 & a B & 4.50 & \pm 0.76 & a A
\end{tabular}

Means followed by the same lowercase letter in the column and uppercase in the row, do not differ statistically (SNK test, $\mathrm{p}<0.05$ ).

TABLE 4 - Stem dry matter of coffee plants in crops with cultivars 144 and IBC 12, submitted to different management types at 120 DAA, Rio Paranaíba, 2018.

\begin{tabular}{lccccrc}
\hline \multicolumn{1}{c}{ Treatments } & IBC 12 & & & 144 & \\
\hline Control & 10.02 & \pm 0.80 & a B & 17.69 & \pm 4.49 & a A \\
Indaziflam & 6.86 & \pm 0.95 & b B & 14.35 & \pm 3.36 & a A \\
Indaziflam + PVC & 6.29 & \pm 1.00 & b B & 17.83 & \pm 7.25 & a A \\
Indaziflam + PVC + manure & 6.67 & \pm 0.35 & b B & 23.83 & \pm 2.99 & a A \\
Indaziflam + manure & 7.72 & \pm 3.44 & b B & 20.75 & \pm 3.99 & a A
\end{tabular}

Means followed by the same lowercase letter in the column and uppercase in the row, do not differ statistically (SNK test, $\mathrm{p}<0.05$ ). 
Carvalho et al. (2014) recommend the planting of seedlings inoculated with FMAs, as they are able to reduce the negative effects of herbicides chlorimuron-ethyl, fomesafen, oxyfluorfen and fluazifop-p-butyl+fomesafen. The reduction in the effects of indaziflam on the root system in the treatments where bovine manure was used may be associated to the increase in the microbial community in the seedling rhizosphere. In addition, Braga (2017), when studying indaziflam sorption in soils with organic matter addition, and Alonso et al. (2016), evaluating the behavior of this herbicide in different soils, conclude that the sorption of this herbicide is directly correlated with the increase in the organic matter of the soil. In this study, the addition of organic matter, in the form of manure, may have reduced the availability of herbicide in the soil solution near the seedlings, thus reducing its damage to the root system.

Leaf area of cultivar 144 was higher than that of IBC 12, except for the use of indaziflam alone (Table 6). All treatments caused leaf area reductions in cultivar IBC 12 , being more aggravating in treatments without the use of manure. For cultivar 144, it was observed that the seedlings where manure was added did not differ from the control treatment. However, without this addition, the reduction in leaf area was highly affected. With the increase in leaf area, there is an increase in the photosynthetic surface of the plant, which is a factor of great importance for the increase in yield (Cannell, 1985).

In this study, it can be observed that the morphological growth of cultivar 144 is naturally superior to that of cultivar IBC 12. Although the treatments with the use of indaziflam cause intoxication in seedlings, it was observed a data reductionin the plants overtime, being insignificant. The cultivar IBC 12 showed minor intoxications by the herbicide. However, this cultivar presented greater damage in the morphological variables. The use of manure with the PVC pipe can be an alternative to reduce the effects of this herbicide, since it reduced the effects of the product on the root system of this cultivar.

TABLE 5 - Root dry matter of the coffee cultivars 144 and IBC 12, submitted to different management types at 120 DAA, Rio Paranaíba, 2018.

\begin{tabular}{|c|c|c|c|c|c|c|}
\hline Treatments & & IBC 1 & & & 144 & \\
\hline Control & 8.72 & \pm 0.45 & a B & 12.64 & \pm 2.00 & a A \\
\hline Indaziflam & 6.42 & \pm 1.17 & b B & 12.56 & \pm 6.81 & a A \\
\hline Indaziflam + PVC & 5.66 & \pm 0.70 & b B & 12.72 & \pm 3.85 & a A \\
\hline Indaziflam + PVC + manure & 8.40 & \pm 1.54 & a B & 17.97 & \pm 6.51 & a A \\
\hline Indaziflam + manure & 7.76 & \pm 3.06 & $\mathrm{ab} B$ & 17.74 & \pm 3.95 & a A \\
\hline
\end{tabular}

Means followed by the same lowercase letter in the column and uppercase in the row, do not differ statistically (SNK test, $\mathrm{p}<0.05$ ).

TABLE 6 - Leaf area of coffee plants in the cultivars 144 and IBC 12, submitted to different management types at 120 DAA, Rio Paranaíba, 2018.

\begin{tabular}{lcccccc}
\hline \multicolumn{1}{c}{ Treatments } & \multicolumn{7}{c}{ IBC 12 } & & 144 \\
\hline Control & 783.25 & \pm 170.05 & a B & 1350.75 & \pm 464.93 & a A \\
Indaziflam & 387.50 & \pm 41.01 & bc A & 582.25 & \pm 370.89 & c A \\
Indaziflam + PVC & 200.00 & \pm 99.40 & c B & 1030.00 & \pm 166.91 & b A \\
Indaziflam + PVC + manure & 544.25 & \pm 214.07 & b B & 1324.25 & \pm 223.92 & a A \\
Indaziflam + manure & 422.75 & \pm 206.75 & bc B & 1274.75 & \pm 195.27 & a A \\
\hline
\end{tabular}

Means followed by the same lowercase letter in the column and uppercase in the row, do not differ statistically (SNK test, $\mathrm{p}<0.05$ ). 


\section{CONCLUSIONS}

The application of indaziflam causes mild injury symptoms in coffee plants, independent of planted cultivar 144 and IBC 12. Indaziflam causes reduction in seedling morphology, and this effect is dependent on the cultivar used. The use of manure associated to the PVC pipe can be an alternative to reduce the effects of indaziflam, mainly in the root system of coffee plants.

\section{REFERENCES}

ALCANTARA, C. B. Desenvolvimento vegetativo de linhagens de cafeeiro (Coffea arabica L.) nas condições de cerrado em Patrocínio-MG. 2012. 51 f. Dissertação (Mestrado em Fitotecnia) - Universidade Federal de Uberlândia, Uberlândia, 2012.

ALONSO, D. G. et al. Sorption and desorption of indaziflam degradates in several agricultural soils. Scientia Agricola, Piracicaba, v.73, n.2, p.169-176, 2016.

BRAGA, R. R. Sorção de indaziflam e isoxaflutole em solos tropicais. 2017. 45f. Tese (Doutorado em Fitotecnia) - Universidade Federal de Viçosa, Viçosa, 2017.

BROSNAN, J. T. et al. Smooth crabgrass control with indaziflam at various spring timings. Weed Technology, Arkansas, v.25, n.3, p.363-366, 2011.

BROSNAN, J. T. et al. Pre and post emergence annual bluegrass control with indaziflam Weed Technology, Arkansas, v.26, n.4, p.661-665, 2012.

BROSNAN, J.T., \& BREEDEN, G.K. Application placement affects postemergence smooth crabgrass (Digitaria ischaemum) and annual bluegrass (Poa апnиа) control with indaziflam Weed Technology, Arkansas, v.26, n.1, p.48-53, 2012.

CANNELL, R. Physiology of the coffee crop. In: CLIFFORD, M.N.; WILLSON, K.C. (Ed.). Coffee: botany, biochemistry and production of beans and beverage. London: Croom Helm, 1985. p.108-134.

CARVALHO, F. P. et al. Deriva de glyphosate afeta a associação micorrízica arbuscular em cafeeiro. Planta Daninha, Viçosa, v. 32, n.4, p.783-789, 2014.

CARVALHO, G.S. et al. Estudo do adensamento de plantio do cafeeiro (Coffea arabica L.) no planalto da conquista. In: III Simpósio de Pesquisa dos Cafés do Brasil, 2003, 3, Porto Seguro. Resumos ... Porto Seguro: Embrapa Café, 2003. p.296.
CHRISTOFFOLETI, P. J. et al. Indaziflam: Novo mecanismo de ação para a cana-de-açúcar. In: Congresso Brasileiro Da Ciência Das Plantas Daninhas, 28, 2012, Campo Grande. Resumos... Campo Grande: Sociedade Brasileira da Ciência das Plantas Daninhas, 2012, p.76-80.

CHRISTOFFOLETI, P. J. et al. Resistência de plantas daninhas a herbicidas: termos e definições. In: CHRISTOFFOLETI, P. J.; OVEJERO, R. F. L.; NICOLAI, M.; VARGAS, L.; CARVALHO, S. J. P.; CATANEO, A. C.; CARVALHO, J. C; MOREIRA, M. S. (Eds.) Aspectos da resistência de plantas daninhas a herbicidas. Piracicaba: HRAC, 2016. p. 11-32.

CONAB. COMPANHIA NACIONAL DE ABASTECIMENTO. Available on: <http://www. sapec.embrapa.br/arquivos/consorcio/levantamento/ conab_safra2018_n4.pdf.>Acesso: Apr. 26, 2019.

EPAMIG - EMPRESA DE PESQUISA AGROPECUÁRIA DE MINAS GERAIS. Seleção de progêenies de "mundo novo" para o programa de melhoramento de Coffea arabica L. Lavras, EPAMIG, 2016, 56 p.

FERREIRA, I. N. M. et al. Caracterização anatômica dos órgãos vegetativos do cafeeiro arábica (Coffea arabica L.). Fragmentos de Cultura, Goiânia, v. 24, n. 1, p. 153-161, 2014.

FIALHO, C. M. T. et al. Interferência de plantas daninhas sobre o crescimento inicial de Coffea arabica. Planta Daninha, Viçosa, v. 29, n. 1, p. 137-147, 2011.

FRANÇA, A. C. et al. Crescimento de cultivares de café arábica submetidos a doses do glyphosate. Planta Daninha, Viçosa, v. 28, n. 3, p. 599-607, 2010.

GUERRA, N. Aminocyclopyrachlor e indaziflam: Seletividade, controle e comportamento no ambiente. Revista Brasileira de Herbicidas, Londrina, v. 12, n. 3, p. 285-295, 2013.

KAAPRO, J., \& HALL, J. Indaziflam, a new herbicide for pre-emergent control of weeds in turf, forestry, industrial vegetation and ornamentals. Pakistan Journal of Weed Science Research, Pakistan, v. 18, p. 267-270, 2012.

MAGALHÃES, C.E.O. Seletividade e controle de plantas daninhas com oxyfluorfen e sulfentrazone na implantação de lavoura de café. Planta Daninha, Viçosa, v. 30, n. 3, p. 607-616, 2012. 
MYERS, D. F.; et al. Indaziflam/BCS AA170717-a new herbicide for preemergent control of grasses and broadleaves in turf and ornamentals. In: Proceedings, Southern Weed Science Society, Florida, 2009, p. 394.

NICOLAI, M. et al. Avaliação da seletividade do herbicida indaziflam ao longo de três anos para a cultura do citros. In: Congresso Brasileiro Da Ciência Das Plantas Daninhas, 28, 2012, Campo Grande. Resumos... Campo Grande: Sociedade Brasileira da Ciência das Plantas Daninhas, 2012, p.81-85.

PAIVA, M. C. G. et al. Fitotoxicidade de herbicidas aplicados em pós transplantio de mudas de maracujá amarelo. Revista Brasileira de Herbicidas, Londrina, v. 14, p. 280-287, 2015.
PERRY, D.H. et al. Indaziflam utilization for controlling problematic turfgrass weeds. Applied Turfgrass Science, Madison, v. 8, n. 1, p. 0-0, 2011.

SILVA, V. F. V. Uso do novo herbicida indaziflam em pomares de banana. Revista Brasileira de Herbicidas, Londrina, v.16, n.4, p.325-332. 2017.

SBCPD - SOCIEDADE BRASILEIRA DA CIÊNCIA DAS PLANTAS DANINHAS. Procedimentos para instalação, avaliação e análise de experimentos com herbicidas. Londrina: SBCPD, 1995, 42 p.

YAMASHITA, O. M. et al. Deriva simulada de herbicidas em mudas de Coffea canephora. Scientia Agraria Paranaensis, Paraná, v. 12, n. 2, p.148-156, 2013. 